\title{
Jesuit-Protestant Encounters in Colonial Congo in the Late Nineteenth Century: Perceptions, Prejudices, and the Competition for African Souls
}

\author{
Toussaint Kafarhire Murhula, s.J.
}

This chapter analyzes the conditions under which Jesuit and Protestant missionaries encountered each other in the Congo in the late nineteenth century. It aims to explain the conflictual relationships that ensued and to address the questions of competition that stemmed from their mutual prejudices and biased perceptions.

In the late nineteenth century, King Leopold II (1835-1909, r.1865-1909) repeatedly asked the Jesuits to take part in his colonizing project in the Congo. However, they were reluctant to do so not only because of the negative opinion they held of the king's colonial ambitions but also because other Catholic missionary orders had been working in the Congo since 1881 . Why, then, did the Belgian Jesuits eventually decide to become involved in Leopold's colonial project despite their previous reluctance to do so? What had changed by 1893, when they agreed to the king's request, and what imperatives were they responding to? Answering these questions will help explain the animosity that resulted from encounters that were marred in mutually distorted perceptions, hostile interpretations, and conflicts of interest.

This essay is divided into four parts. The first part sets out the political context of the late nineteenth century, a period in which the European powers were scrambling for colonial supremacy in Africa. The second part outlines the discussion process that eventually led the Jesuits to take part in the project as civilizing agents. The third part analyzes the way in which Jesuits and Protestants perceived each other. On the one hand, the political connections and preferential status of the Roman Catholic Church within the colonial structure gave the Jesuits a sense of entitlement in fending off the spread of the Protestant "heresy." On the other, the Protestant Baptist missionaries saw this group of Catholic missionaries reaping temporal privileges from the state as imposters posing as religious. The chapter concludes by reflecting on the foregoing analysis and discussing future lines of enquiry. 


\section{Setting the Political and Historical Context}

The conflict-ridden background to the Jesuit-Protestant encounter in the Congo coincided with the late nineteenth-century colonial scramble for Africa. Competitions and rivalries among the European colonial powers would determine both the kinds of social policies that were adopted and the missionary group to be sent to a given territory and supported by the state. ${ }^{1}$ Thus the history of the nineteenth-century penetration of Christian missionaries into Africa is, to a large degree, the history of European colonization. ${ }^{2}$

Belgian colonial rule in the Congo was characterized by a unique structure of institutionalized violence and unprecedented brutality, where the colonial agents (administrators, soldiers, and priests) symbolized the very raison d'être of the colonial state, namely to maximize the commercial interests and profits of the multinational Western companies that ventured into the Congo in the king's name. To meet their goals, the colonial agents had to push the Congolese natives to deliver a daily quota of rubber and ivory tusks, the precious global commodities of the day. The African colonial experience consequently signified the Western project of reorganizing both the geographical space and the minds of native populations and, concomitantly, of forcing Africans into Western modernity.

At the 1884 Berlin Conference, Leopold was granted permission to occupy the vast territory of the Congo, with international recognition of the king's colony to be provided at a later date. In order to raise the much-needed capital to begin exploiting the natural resources in his newly acquired property, Leopold invited multinational companies to invest in the Congo, calling, at the same time, on Catholic missionaries to carry out the work of "civilization"

1 Joseph Conrad, Heart of Darkness \& Selections from the Congo Diary (New York: Modern Library, 1999). This novella provides a powerful allegory of the colonial horrors and brutalities. In the introduction to this edition, Caryl Phillips argues that Conrad's "iconic tale of rescue $[. .$.$] contains a powerful meditation on the relationship between 'civilization' and$ 'barbarity." See the "Introduction," in Conrad, Heart of Darkness, xi-xviii. Also, Adam Hochschild's King Leopold's Ghost: A Story of Greed, Terror, and Heroism in Colonial Africa (New York: First Mariner Book, 1999) provides another scholarly analysis that depicts the historical background to the colonial for-profit business and the related atrocities that accompanied these ventures in the Congo. See also Ruth Mayer, Artificial Africas: Colonial Images in Times of Globalization (Hanover: University Press of New England, 2002) and David Van Reybrouck, Congo: The Epic History of a People (New York: HarperCollins, 2014).

2 V.Y. [Victor Yves] Mudimbe, The Invention of Africa: Gnosis, Philosophy, and the Order of Knowledge (Bloomington: Indiana University Press, 1988), 45-46. 
(i.e., education). The state would provide soldiers to protect these agents and guarantee them a propitious working environment. Thus land came to be granted by the state to multinationals and to the church thanks to a royal decree that destroyed the traditional African systems of communal ownership of land and its products. The decree allowed the colonial administration to expel the natives from their lands by declaring any "vacant land" to be the property of the state. ${ }^{3}$ But the colonial definition of unoccupied land, as American historian Catherine Ann Cline argues, was contrary to the customs of the land, a form of trickery that gradually led to the imposition of a labor tax on the population. This self-financing policy undoubtedly raised vast amounts of revenue for the king and, eventually, the state; the human toll, however, was utterly appalling. ${ }^{4}$

How did King Leopold II of the tiny Belgian realm manage to secure the vast territory of the Congo as his personal property when European powers, such as France, Britain, Germany, Spain, and Portugal, were competing for access and control of smaller colonial territories in much drier regions? When they met in Berlin in 1884, the goal of these European powers was not only to resolve their competing claims and interests over the newly discovered Congo River Basin but also to regulate trade relations on the continent. ${ }^{5}$

Leopold emerged on the international scene at the Berlin Conference as a benevolent, selfless leader. He presented himself as being interested only in opening up the heart of Africa to civilization, free trade, and Christianity. In 1876, for instance, he had hosted the International Geographical Conference in Brussels, the outcome of which led him to found the International African Association (IAA). Three years later, in 1879, Leopold commissioned the famous Welsh American explorer Henry Morton Stanley (1841-1904), under the banner of the International Association of the Congo (IAC), to establish treaties with local leaders and commercial outposts in the Congo. ${ }^{6}$ Stanley left on his third trip for the Congo in 1879 - after the first to find the lost David Livingstone (1813-73) in 1871 and the second to explore the Congo River Basin (1874-77) as an agent of Leopold. During this trip, he mapped the country's physical

3 Hochschild, King Leopold's Ghost, 111-19.

4 Catherine Ann Cline, "The Church and the Movement for Congo Reform," Church History: Studies in Christianity and Culture 32, no. 1 (1963): 46-56, here 48.

5 Kevin C. Dunn, Imagining the Congo: The International Relations of Identity (New York: Palgrave Macmillan, 2003), 22.

6 Victor Yves Mudimbe, The Idea of Africa (Bloomington: Indiana University Press, 1994), 105; see also Dunn, Imagining the Congo, 21-23. 
terrain and established some commercial outposts (1879-84), thus producing the Congo that was to be handed over to the king at the Berlin Conference.

Since the European powers intended to keep the Congo River Basin for the collective exploitation of all, awarding the management of the Congo to Leopold was a strategic move designed to create an "international colony" with the king of Belgium at its helm. Although the IAC was a private company and not a government, the international community granted it recognition and gave Leopold juridical sovereignty over the entire region. Hence, with the agreement and the protection of the European powers, the Berlin Conference allowed Leopold to collapse his IAC into the Congo Free State (CFS) on May 29, 1885. As political scientist Kevin Dunn observes, Leopold was able to weather the storm of those contesting this move by maintaining his image as a philanthropist fighting the Arab slave trade and by continuing to make promises of free trade and neutrality.

To convince the leaders of the European powers that he could run the Congo in the interests of all, Leopold cleverly used the good faith of the Protestant missionaries who had been working in the Congo since 1878 and who were able to influence public opinion in their respective countries. To ensure their support, he promised them freedom of religion in the Congo, and thus, as historian Ruth Reardon Slade explains, "it was not surprising that the Protestants were on the side of Leopold II," since the Catholic missions were still closely connected with the political ambitions of France and Portugal. ${ }^{7}$ The Protestant missionaries, for their part, feared that the Portuguese would use their ius patronatus (right of patronage) to achieve missionary sovereignty in the Lower Congo. The papal establishment of the ius patronatus over all countries discovered or to be discovered granted European kings the right to dispossess non-Christians of their lands and became, in the international context of the day, a way to justify the concept of terra nullius (no-man's-land).

It is important to say a word about the right of patronage here. From the fifteenth century onward, the missionaries' agenda was much more complex than the simple transmission of the Christian faith, since the missionaries themselves were part of a political process that created and extended European sovereignty over newly discovered territories. Through his bulls Dum diversas (1452) and Romanus pontifex (1455), Pope Nicholas V (1397-1455, r.1447-55) had granted the Portuguese king the right to invade and occupy pagan kingdoms

7 Ruth Slade Reardon, "Catholics and Protestants in the Congo," in Christianity in Tropical Africa, ed. C.G. [Christian Goncalves] Baëta (Oxford: International African Institute and Oxford University Press, 1968), 83-100, here 85 . 
or dispossess them of private property and land. Christian kings consequently acquired the right to enslave Muslims, pagans, and black people. ${ }^{8}$

The pope delegated the power to evangelize throughout the world to Spain in 1508 and to Portugal in 1514- the two major colonial powers of the dayboth of which possessed important maritime fleets. As one scholar has noted, the resulting system of "patronage," which was an immediate solution to the problem of evangelization, nevertheless contained the seed of political and economic conflicts of interests among the powers opposed to the church's evangelizing mission. It was only when other colonial powers began to compete and when the financial and material means of Portugal and Spain began to decline that the Roman Catholic Church decided to create the Congregation de Propaganda Fide in 1622 with the goal of centralizing and guiding the missions. At that point, the Catholic Church began to go against the patronage system. ${ }^{9}$

Accordingly, the king was responsible for funding evangelization work and the building of churches; he also had a say in the appointment of bishops. ${ }^{10}$ As a result of this development, the Protestants came to believe that they had discovered a potential ally in the person of Leopold, who had promised to maintain freedom of religion in the Congo. On this specific point, political scientist Marvin D. Markowitz notes,

Leopold welcomed and cultivated the support of the Protestant missionaries, and aided their efforts to build mission stations in the Upper Congo. There can be little doubt that the aid of the Protestant missions

$8 \quad$ Mudimbe, Invention of Africa, 45 .

9 The aim in creating the Congregation de Propaganda Fide in 1622 was, for the Vatican, to centralize and reclaim control over the missions in revocation of papal bulls that delegated this responsibility to European superpowers during the fifteenth and sixteenth centuries. The Catholic Church continued, however, to depend on European countries, at least for granting the right to their missionaries to travel and work in the colonies. See Yves Krumenacker, “Le XvıIIe siècle: Éveil protestant et déclin catholique?" Cahiers d'études du religieux: Recherches interdisciplinaires 1 (2008); posted online on January 25, 2008 at http://cerri.revues.org/242 (accessed May 22, 2017).

10 In his Idea of Africa, 30-33, Mudimbe discusses the way in which different papal bulls dealt with this right of patronage, imparting the responsibility to evangelize newly discovered territories to Catholic kings of Spain and Portugal. Among others, the documents included Romanus pontifex (1454), Inter caetera (1493), Universalis ecclesiae (1508), and Dudum pro parte (1516). 
had been helpful, if not instrumental, in obtaining the establishment of Leopold's dominion in the Congo under the Berlin Act of $1885 .{ }^{11}$

Once he had been granted the Congo, Leopold went on to use both the state and the church, that is, the soldiers and the missionaries, to achieve his colonial goals. These consisted in spreading European civilization, making room for free commerce, and bringing the light of Christianity to the Africans. As "effective" occupation of the territory was required in the Berlin Conference Act in order to claim colonial authority over a territory, the king not only needed more military men from Belgium; he also sought to form a military body from among the natives in the Congo. Hence, by adopting a strategy of cultivating and redesigning the territorial space and the natives' minds on the basis of modern Western rationality, Leopold sought to orient both the colonial agents and the local populations to support his project.

Yet, to achieve his vision, the exclusive contribution of Belgian Catholic missionaries, especially the Jesuits, was needed. The question therefore remains why the Jesuits came to accept the king's request, enabling him to blend the Berlin Conference's requirement of effective occupation with his ambition to exploit the colony for commercial profit.

\section{The Jesuit Decision to Take Part in Belgium's Colonial Project}

The generally accepted narrative is that the Jesuits, who arrived in the Congo fifteen years after the Protestants, enjoyed a privileged position in the country until after the Second World War thanks to their Belgian nationality and assumed patriotism. However, this narrative fails to acknowledge the existence of conflicts between the Catholic Church and the colonial state on the one hand, and the numerous cases of collaboration between Jesuits and Protestants within the Congo on the other. Although personal acts of Christian generosity between individual Jesuits and Protestants cannot override the existing pattern of conflict, this essay contends that, more than anything else, it was national patriotism and international competition, more than anything else, that informed state policies and the individual attitudes of these missionaries. The Jesuits' privileged position put the Protestants at a disadvantage, allowing them to turn a blind eye to the atrocities perpetrated by the colonial

11 Marvin D. Markowitz, "The Missions and Political Development in the Congo," Africa: Journal of the International African Institute 40, no. 3 (1970): 234-47, here 234. 
agents against local populations, whereas the Protestants saw an opportunity to denounce an unacceptable system of intolerable violence. Political scientist Patrick Boyle cogently summarizes what was at stake in the colonial Congo state, namely the "respective status of Catholic and Protestant missionaries in the territory, as well as the practice among EIC (État Indépendant du Congo) [Congo Free State] agents of placing Congolese children in military camps called colonies scolaires [school camps]."12

The first group of Jesuits, which was made up of only three men - two priests, Emiel van Hencxthoven (1852-1906) and Jean-Baptiste Dumont (1843-93), and one brother, Edmond Lombary (1865-1918) — departed from Antwerp on March 6, 1893. A day before their departure, Mass was celebrated in the Cathedral of Our Lady of Antwerp with their families in attendance. Other Jesuits were also present at Mass, as were some officials representing the CFS. These three groups represented the state, the Catholic Church, and the broader public - the different stakeholders in the colonial business in the Congo that novelist Joseph Conrad (1857-1924) would later term "the heart of darkness." The three men arrived at their destination more than three weeks later, on March 30, 1893. A second group then set out on April 6, 1893 to join the first three pioneers. This second group was composed of Father Edouard Liagre (1853-99), Emile de Meulemeester (still a scholastic), and two brothers, Justin Gillet (1866-1943) and Frans de Sadeleer (1844-1922). The group also contained two laymen, Charles Petit and Auguste van Houtte.

While the king was anxious to achieve his dream in the Congo, attracting Belgian missionaries was a strategic and necessary move toward that end. After securing the coveted territory of the Congo, he indeed no longer needed the support of Protestant missionaries to influence British public opinion. His goal was now to replace these British as well as other non-Belgian Catholic missionaries altogether. Leopold used his diplomatic skills to convince the Vatican that only Belgian Catholic missionaries would ensure unity of vision in the colony. As a result, in 1886 Pope Leo XIII (1810-1903, r.1878-1903), initiator of the Catholic Social Teaching with his encyclical Rerum novarum of 1891, agreed

12 Patrick M. Boyle, "School Wars: Church, State, and the Death of the Congo," Journal of Modern African Studies 33, no. 3 (1995): 451-68, here 451. It is important to say a word on the colonies scolaires. Historian Léon de Saint Moulin discusses their foundation by a royal decree signed on July 12, 1890, a decree that placed under the tutelage of the state native children who were redeemed from Arab slave-owners as well as orphans and other abandoned children-whose parents were unable to meet the needs for education. See Léon de Saint Moulin, "Le Père Emile Van Hencxthoven, fondateur de la mission du Kwango," in Actes du colloque de Kimwenza, décembre 1993 (Kinshasa: Province d'Afrique Centrale, 1994), 12. 
that the territory of the Congo should be reserved for Belgian missionaries. Three years later, in 1889, the pope accordingly wrote to the superior general of the Scheut Fathers entrusting the mission of evangelizing the Congo to the newly founded order:

You are without ignoring, dear Sons, Our ardent desire to see the savage peoples of Africa abandon the darkness of error for the brilliance of the light of the Gospel and to exchange their dullest customs with politeness and Christian civilization. This change will have the effect of (1) exempting from the law of their caprices these tribes, which are reduced to the level of the animal state; and of (2) making them pass from the servitude of corruption to the glorious liberty of the children of God. ${ }^{13}$

This was the prevailing perception of the Africans in the Western collective consciousness: savage people living in the darkness of error, with dull and brutish cultures at the limit of the animal state. At the First Vatican Council in 1869-70, prelates evaluated the so-called curse of Ham and recognized the necessity to bring the light of Christ to the interior of Africa. The work of civilization thus necessitated an army of volunteer missionaries to respond to the call of the humanitarian crisis that besieged Africa. Indeed, the nineteenthcentury scramble for Africa took place within an atmosphere of Catholic missionary revival after the criticism of the eighteenth century had come to an end. Leopold had persuaded one of the major figures of the late nineteenthcentury revival of the Catholic missionary effort, the French cardinal Charles Lavigerie (1825-92) — founder of the Missionaries of Africa, commonly known as the White Fathers- White Fathers in the eastern part of the Congo State, and by 1888 he [Leopold] had succeeded in getting Flemish Scheut Fathers to take an interest in the Congo."14 As Lavigerie went across Europe in the same year preaching against the horrors of the Arab slave trade, Catholics in Belgium began to see acting in the CFS as a religious and humanitarian duty. This change of sentiment was attributed to Lavigerie's preaching, in which he likened Leopold to the sower of good seed and the Arab traders as the enemies who stole in and sowed tares. It was in this context that the king convened an anti-slavery conference in Brussels from November 18, 1889 to July 11890 , as a result of which the European powers not only assumed the moral duty to deal with the Arab slave trade but

13 Quoted in Jules Chômé, Indépendance congolaise: Pacifique conquête (Brussels: Editions de Remarques Congolaises, 1960), 5 (my translation).

14 Slade, "Catholics and Protestants in the Congo," 86. 
also accorded Leopold the right to exact a ten percent import duty hitherto forbidden by the free trade provision under the Berlin Act. The Belgian government also granted a loan of twenty-five million francs to the CFS, money that would further encourage Catholic missionary work in the Congo. ${ }^{15}$

However, in addition to involving Belgian Jesuits in the education and religious training of children redeemed from Arab slave-traders, Leopold also ordered the facilitation of the Jesuits' "settlement in every possible way. They were freely given large concessions of land, while their personnel and goods were often transported in the State steamers."16 The intertwining of the state and the Catholic Church was critical not only in the acquisition of "seed" converts to begin the mission with but also in the material assistance that the government provided to Catholic missionaries. ${ }^{17}$

Leopold explained his vision in an autographed note, sent on April 27, 1890, to the administrator of the CFS, Edmond van Eetvelde (1852-1925). In the note, he stated that he intended to establish three colonies of children (colonies d'enfants): "I am of the mindset to open three big colonies of children. One in the Upper Congo, toward Equator, uniquely set for military purposes. We will have the fathers to provide their religious and professional education. The other in Leopoldville $[\ldots]$ and the third one in Boma [...]." ${ }^{\prime 18}$ In reality, these camps were ghetto-like settlements in which native children were confined for the sake of education. When the Jesuits arrived in the Congo in 1893, there were already "eighty-five children whom the state had confiscated from the Arabized slave traders," on top of seventeen freed slaves, twelve workers, two carpenters, and two soldiers and their wives. ${ }^{19}$

Obviously, Leopold's intention was neither to create a native elite nor to educate free men by entrusting the colonies scolaires to the Jesuits for the education of children. On the contrary, the presence of the Jesuits was dictated by the desire to oust Protestantism, and at the same time, to educate and

15 Cline, "Church and Movement for Congo Reform," 47; Mudimbe, Idea of Africa, 46.

16 Slade, "Catholics and Protestants in the Congo," 86.

17 Historian Robert E. Smith demonstrates this close collaboration by relating a Jesuit mission superior's insistence that his subjects show great esteem to the state authority and underscore Belgium's civilizing mission in the Congo; see Robert E. Smith, "Here we are in full battle': Jesuits and Baptists in the Kwilu, Congo," American Baptist Quarterly 22, no. 2 (2003): 180-211. André Knockaert, a Jesuit priest, translated this article into French, which was then published in Telema (Lève-toi et Marche) 2-3, nos. 121-22 (2005): 114-42, here 119 .

18 Quoted in Fernand Mukoso Ng'Ekieb, Les origines et les débuts de la mission du Kwango (1879-1914) (Kinshasa: Facultés Catholiques de Kinshasa, 1993), 41 (my translation).

19 Van Reybrouck, Congo, 73. 
evangelize the natives. By the same token, these sons of Belgium would show more "nationalist" loyalty to the king's colonizing project, unlike their Protestant counterparts whose presence came to be perceived as undermining colonial unity. The king sought to raise and recruit eighty percent of these children for military purposes in the colony while the remaining twenty percent was left to serve the missionaries who in turn selected a few among them to become catechists. Thus, "the Jesuits fought for Jesus, but also for Leopold," as Belgian cultural historian David Van Reybrouck puts it.

Before examining the role of the catechists in the Jesuit and Protestant encounter in the Congo, it is important to pause here to consider the discernment process that led the Jesuits' to agree to take part in Leopold's project. The Jesuit decision to accept this mission did not come easily. On two occasions, the king had attempted to rally them to his colonial dream, but the Society of Jesus had declined both times. The first request was in 1879 . Later, in 1885 , the provincial superior of the Belgian Jesuits, Father Joseph van Reeth (1843-1923), explained to Father Anthony Anderledy (1819-92), then vicar general of the Society of Jesus during Superior General Peter Jan Beckx's (1795-1887, in office 1853-87) illness, of his decision to decline the king's offer. He argued that his province had already sent four men (two priests and two brothers) the previous year to open a mission in the Upper Zambezi. ${ }^{20} \mathrm{He}$ then summarized the province consultors' discernment in the following six reasons that motivated the province's refusal. ${ }^{21}$

The first of these was that the Jesuits believed that the king needed to go through the proper channels and talk to the Vatican hierarchy, since the distribution of missions was a prerogative of the Congregation de Propaganda de Fide, particularly as the latter had already assigned the evangelizing mission of the Congo to the White Fathers and the Holy Ghost Fathers. ${ }^{22}$ Second, the Belgian province did not have enough men for its own colleges in Belgium and Calcutta, and it had already made a major sacrifice in sending men to the Zambezi Mission in the previous year. Third, the experience of sending men to Guatemala in 1843 , in haste and with little preparation, had resulted in a major failure and there was no point repeating the same mistake. Fourth, there was an obvious conflict of interest between Catholic missionaries and the

$20 \quad$ Ng'Ekieb, Les origines et les débuts de la mission, 40.

21 Letter from the provincial of Belgium to the general, May 5, 1885; cited by Gérard Ciparisse, "Les tractations en vue de la création de la mission du Kwango: Le dossier de la Compagnie de Jésus (1879-1893)," Bulletin de l'Institut Historique Belge de Rome 42 (1972): 453-572, here 499-500. Quoted in Saint Moulin, "Le Père Emile Van Hencxthoven," 12nı. 
European adventurers attached to the colony. The notorious violence of the latter clashed with the goals of evangelization and moralization of the former. Fifth, Catholics in Belgium were suspicious of the king's colonial enterprise. And, finally, the expeditions sent to the Congo had not yet produced any significant results as compared with the investment made. In response, the general commended the provincial and the question was considered settled.

The king then tried a second time to encourage the Jesuits to take part in his colonial project. This request came after the king's diplomatic feat at the Berlin Conference in 1885 and despite the suspicions of Catholics in Belgium, who opposed the king's duplicitous policy of religious neutrality given the widespread belief that Leopold was simply playing politics to garner support from the Protestant churches working in the Congo. At Leopold's urging, in a sermon delivered in 1888, Lavigerie criticized Belgian Catholics for their lack of support for the king's African project. ${ }^{23}$ The king had considered Father Charles Croonenberghs (1843-99) to be a potential head of the Belgian Jesuit mission in the Congo because of his missionary experience in India and in the Zambezi. Three times, the secretary general of the CFs had invited Croonenberghs to speak about Africa. On the third occasion, Croonenberghs wrote to the Jesuit superior general, reporting: "Last month, a high-ranking official came to enquire whether the Society of Jesus would like to take part in the colonial work of the king in Africa. I have no doubt that the king himself had sent this man." ${ }^{24}$

Having learned of the proper channel to force Jesuits into obedience, Leopold sent an official request for Catholic missionaries to the Congregation de Propaganda de Fide, in which he explicitly referred to the Jesuits. As mentioned earlier, one of the reasons he needed Belgian missionaries was also to preempt the Portuguese from using their "right of patronage," which, according to the king, would undermine "the administrative unity of the Congo Free State [l'unitéadministrative dans le nouvel Etat]."25 Historian Yves Krumenacker remarks that conflicts did exist between the Congregation de Propaganda de Fide and Portugal on the question of prelates to be sent to Latin America, as well as on the control of the missions in its territories. If the king feared Catholic missionaries of other nationalities, then he had every reason to perceive Anglo-Saxon Protestant missionaries as a grave threat to his colonial project. After receiving his request, the Congregation de Propaganda de Fide contacted the Society's vicar general, Anderledy, who then relayed it to the provincial

\footnotetext{
23 Cline, "Church and Movement for Congo Reform," 46-47.

24 Ng'Ekieb, Les origines et les débuts de la mission, 39.

25 Krumenacker, "Le Xviı siècle."
} 
superior in Belgium. After examining whether there had been any changes in the situation since the first refusal in 1879 , the provincial decided to adopt a prudent attitude and wait, rather than getting drawn in by

some adventurous Europeans without resources, without morals, and without faith; having no respect for priests and neutralizing our influence on the natives by their words and examples; [a place] where it was likely that liberals and even Free-masons have a large share in the government and the administration. ${ }^{26}$

Although it would appear that the king took personal offense at this second refusal, he did not give up. In the aforementioned autographed letter to van Eetvelde, Leopold explained his plan to educate children rescued from the Arab slave-traders. The king's third request arrived in 1890, after the Brussels anti-slavery conference. He again recommended asking the Jesuits for their opinion about running these children's colonies. At the conference, the European powers allowed Leopold to levy a ten percent tax on commerce and agreed to involve Belgian Catholic missionaries in the education of children rescued from slavery. ${ }^{27}$ This time, the Jesuits accepted Leopold's invitation.

Several factors motivated this change in attitude. First, the fear that the Zambezi Mission would drain the province's personnel was no longer a concern since the mission had failed to expand. Second, many Jesuits in the province were beginning to feel unease with the order's repeated rejections of the king's invitations. Third, due to domestic politics in Belgium, in which liberals had succeeded in passing a law that established a state monopoly over the education of children, and in order to counter rising anticlericalism, the Jesuits felt that this was an opportune moment to secure the king's favors. A fourth reason could also be added, which is that the Scheut Fathers-who were still a young congregation - had eventually accepted a mission in the Congo in $1888 .^{28}$ Realizing that the Jesuits were now inclined to agree to his request, the king sent an official letter to the provincial on May 12, 1890 and the Jesuits formally agreed to take part in the missionary work in the Congo. After three years spent making the necessary administrative and material preparations, the Jesuits finally sailed for the Congo to help implement Leopold's vision for the native Congolese.

\footnotetext{
$26 \quad$ Ng'Ekieb, Les origines et les débuts de la mission, 40.

27 Ibid., 41.

28 Ibid., 43 .
} 


\section{Perceptions, Prejudices, and Conflicts between Catholics and Protestants}

On their arrival, two major challenges awaited the Jesuits, namely a hostile physical environment and the presence of Protestant missionaries in the country. ${ }^{29}$ The Protestants viewed the king's insistence on using Belgian Catholic missionaries as a strategy designed to counteract the danger that Protestant missionaries would expose Leopold's exploitation of children and the atrocities visited on entire villages. Consequently, the Catholic presence came to be perceived by Protestants not only as a threat to their own presence in the Congo but also as being intimately associated with the king's cover-up strategy. In other words, the conflict between Protestants and Jesuits played out on two different levels. On the Protestant side, it was interpreted through the lens of political and economic interests, whereas, on the Catholic side, it was viewed more through an ideological or theological lens, in which the Catholics viewed the Protestants as "heretics."

Thus, the nature of the conflicts between Belgian Jesuit missionaries and the missionaries from the American Baptist Foreign Missionary Society (ABFMS) derived from the late nineteenth-century political zeitgeist. That is, the missionary scramble for the souls of the native Africans was symptomatic of the colonial scramble for Africa's lands and resources. ${ }^{30}$ This difficult situation endured throughout the first half of the twentieth century, reflecting the conflicting missionary interests and the differences between the two groups in understanding what role the church ought to play in the colonial mission of the state.

Arguably, philanthropy inspired the missionary zeal and the preaching of the Kingdom of God of the Protestants who went to the Congo in 1878. Historian Gösta Stenström notes that, sometime in May 1877, even before Stanley had reached the mouth of the Congo River in August of the same year, the British millionaire Robert Arthington (1823-1900) had contacted the Baptist Missionary Society (BMS) in London with an offer of one thousand pounds if the BMS immediately traveled to the populations lost in the darkness of the Congo in order to bring them the light of the blessed Gospel of Christ. ${ }^{31}$ When the first Protestant missionaries arrived in the Lower Congo in 1878 , they

29 Ibid.; see also Actes du colloque de Kimwenza, décembre 1993 (Kinshasa: Province d'Afrique Centrale, 1994).

$30 \quad$ Smith, "Here we are in full battle."

31 Gösta Stenström, The Brussels Archives, 1922-1968 (Uppsala: Swedish Institute of Mission Research, 2009), 66. 
encountered some vestiges of the early Jesuit evangelization of the sixteenth and seventeenth centuries. As one B MS missionary, William Holman Bentley (1855-1905), reports, the only things that he found in 1879 "were some ruins of an ancient cathedral, a crucifix among other fetishes of the king, and some confused memories of the previous teaching." ${ }^{32}$

While the Jesuits preached obedience to the civil authority, the Protestants took it upon themselves to promote freedom of religion and to protect the natives against the abuses of the state in the "Red Rubber" scandal. The rubber economic boom during the 1890 s led the Congo to become an important source of latex due to the high demand for car and bicycle tires. Given the king's ownership of the Congo and the state's rights on vacant lands, Congolese officials imposed a daily quota of rubber to be delivered to the state, creating a draconian system of forced labor that led to the deaths of hundreds of thousands of people while pushing millions of others to starvation. ${ }^{33}$ Protestant missionaries wrote numerous reports exposing the atrocities of the CFS:

From the Congo Mission Balolo, in the province of Equateur, and from Swedish and American missionaries in the Lower-Congo, reports were reaching us providing details about entire villages that were burnt to ashes when their inhabitants failed to meet the required quotas of their assigned work. In 1895, one report was sent by [George] Greenfell and in 1896 , another report by the Swedish missionary [E.V.] Sjöholm about maltreatment and atrocities imposed on the population. ${ }^{34}$

The Congolese colonial project was clearly conceptualized as an economic venture, unlike other colonies that were primarily framed as political enterprises. The consequence was the subjection of the Congolese people to extreme forms of forced labor that aimed at yielding the highest level of revenue for the state treasury and for Leopold's own personal gain.

When the Jesuits arrived in the Congo in 1893, the "Red Rubber" scandal was already in full-swing. The Jesuits were aware of the atrocities the CFS was committing against the natives, since this was one of the reasons they had refused to accept the king's original invitations in the first place. Yet they also enjoyed a position of privilege. They felt a need to cooperate with the administration,

32 Ibid., 62-63.

33 Jason K. Stearns, Dancing in the Glory of Monsters: The Collapse of the Congo and the Great War of Africa (New York: PublicAffairs, 2011), 23. Also, Saint Moulin, "Le Père Emile Van Hencxthoven," 30 .

34 Ibid., 75 . 
recognized the support they received, and shared the same goal as the state, namely to bring about civilization, although the two used different paths to reach that goal. ${ }^{35}$ Catholics used this privileged position within the colonial state system to intimidate or dislodge Protestants from villages that the latter had occupied. When the Congo was taken away from Leopold in 1908 and became a Belgian colony, Catholic missionaries remained silent about the colonial abuses of human rights. The Protestant missionaries interpreted this attitude as resulting from Catholic collaboration with the state.

Unlike the Catholics, Protestant missionaries were engaged in open campaigns to denounce the brutalities, atrocities, and violence perpetrated by colonial agents against the natives. Since most of them were foreigners, not Belgians, public opinion in Belgium grew increasingly hostile and the king saw in these erstwhile allies dangerous opponents to his vision and goals in Central Africa. As one scholar has argued,

It was when the Protestant missionaries began to take part in this Congo reform campaign that they came into direct conflict with the State authorities. Prudence had made them very slow to speak out in public criticism of the administrative methods of the Congo government, but once they had decided that this was the right course for them, their eyewitness atrocity stories figured largely in the literature of the campaign. The Catholic mission, on the other hand, pursued a policy of private representation rather than public criticism - their situation vis-à-vis the State was considerably more delicate than that of the Protestants in view of the subsidies and State help which they were receiving - and Leopold II did all that he could to use them in combating the propagandists who were attacking the State regime. ${ }^{36}$

Thus, for the king, there was an urgent need to replace the Protestants with Belgian Catholic missionaries whose abiding loyalty and patriotic sentiments would ensure, rather than undermine, the new state's administrative unity. Viewed within this context, the Catholic Church appears to have been an instrument of subjugation and as being complicit in the colonial state's policy of exploiting the native population. Nevertheless, each camp viewed and accused the other of betraying the very Gospel they claimed to bring to black Africans.

When Protestant missionaries at the General Congo Protestant Missionary Conference signed a memorandum in 1906 to be sent to all the Western powers

35 Smith, "Here we are in full battle," 120.

36 Slade, "Catholics and Protestants in the Congo," 87. 
they represented denouncing the colonial atrocities in the CFS, the Catholic Church was busy striking a concordat with the CFS. As a result of this agreement, two hundred hectares of land in free and perpetual concession were granted to the Catholic missions while a stipend would also be paid by the government to the Catholic missionaries. In return, the priests would preach loyalty to the state and work to produce docile citizens. ${ }^{37}$

For such advantages, the Protestants believed, the Catholics had turned a blind eye to the colonial plight of the Congolese natives. As Baptist missionary and historian Robert Smith notes, van Hencxthoven himself, the founder of the Jesuit mission in the Congo, downplayed the colonial brutalities in a letter dating from 1903 in which he wrote that what was happening in the Congo "happens everywhere in the world. The Congolese state is trying to eradicate those criminal ways of acting. The State is doing so much for the Blacks so as to make their rights respected." ${ }^{38}$ As a result, the Protestant missionaries felt discriminated against on many fronts, not least when it came to the ownership of land: whereas Jesuits ended up with 37,208 hectares of land by 1913 as a result of the 1906 concordat, the Protestants had only 209 hectares. The government also subsidized Catholic schools, which were nurseries for state agents and church converts, thus putting the Protestants at a considerable competitive disadvantage.

Schools had become centers for proselytization, and with the state support that they enjoyed, Catholic schools attracted more children than Protestant schools. This state of unfairness was exacerbated by the state's tendency to grant Jesuits a monopoly in running the schools founded on the concessions of multinational societies.

Hospitals also became centers for proselytization. The Jesuits were impressed by the success of the Protestants in the medical field, which was used to attract villagers into their religious turf. More than fifty villages had agreed to convert to Protestantism because of the influence exerted by the Vanga hospital, which had been created in 1913. As a result, the Jesuits went on to found a hospital in Djuma in 1919 in order to counter this Protestant influence. ${ }^{39}$ Yet Protestants developed grudges against the colonial administration regarding the healthcare service because they were given only one percent of the medical budget, even though they provided twenty percent of the $250 \mathrm{doc}-$ tors working in the Congo at that time. ${ }^{40}$

\footnotetext{
37 Smith, "Here we are in full battle," 121.

38 Ibid., 118 .

39 Slade, "Catholics and Protestants in the Congo," 89.

$40 \quad$ Smith, "Here we are in full battle," 122.
} 
Thus, on the Catholic side, the founding of most Jesuit mission posts was dictated by the imperative of stopping the progress of Protestantism. To fend off the spread of Protestant heresy, the Jesuits adopted a strategy of first acquiring land, then training three catechists who were sent to occupy that land, and finally attracting more children into what were called farm-chapels, the missionary secondary posts established near one or several villages with the consent of the local chiefs. As an intermediary space between African societies and Western modernity, historian Victor Yves Mudimbe calls this hyphenated geography "the marginal space."41 Without severing themselves from their families and traditional environments, the children in the farm-chapels spent time in contact with a new way of thinking, being, and doing. They received catechism lessons and were also trained in farming and other subjects. Between 1895 and 1902, the Jesuits created more than 250 farm-chapels in the Congo. ${ }^{42}$ It would appear that the first person to use the term "farm-chapel" was Brother Gillet in a letter of June 1896, in which he explains:

The farm-chapels have for mission to disseminate all around, in a quick and easy manner, the practical knowledge of our religion. They are established with the authorization of the indigenous chiefs, on the outskirts of one or several villages. Each is comprised of a principal chimbeck [rudimentary housing], the place where all gather for spiritual exercises, next to which are built the housing structure for our young Christians. Thatched huts provide shelter for the livestock that we provided to them: chickens, pigs, goats, sheep, etc. Others contained work tools, harvests that were already gathered from cleared fields, and which were being used by our colonial authorities. To ensure a good use of these posts, we ourselves go often to visit them [...]. Besides, all the catechists from the farm-chapels return to Kisantu every Saturday. ${ }^{43}$

As Boyle observes, it is not without reason that Catholic missions, and more specifically the Jesuit ones, were criticized by the liberal Belgian government in a report in 1954 as comparable to the Paraguayan reductions:

Incontestably, on both the religious and political level, the missionary deals with people as a sovereign with his vassals; respected by some,

\footnotetext{
41 Mudimbe, Invention of Africa, 17.

42 Edouard de Moreau, Les missions belges de 1804-1930 (Brussels: Editions Jos. Vermant, 1933), 98-99.

43 Saint Moulin, "Le Père Emile Van Hencxthoven," 37-38.
} 
feared by others, but always obeyed, always making the rules in a way that brings to mind $[\ldots]$ his own narrow self-interest [rather] than the great interest of the population as a whole. ${ }^{44}$

At the level of perceptions, and given that Protestantism started with the rejection of the pope's authority as the vicar of Christ on earth, Jesuits viewed Protestants as heretics and enemies of the Catholic faith. It was written in the DNA of Protestantism, Jesuits believed, to undermine the principle of authority. This belief was so widespread among Catholics that one bishop, Jean Félix de Hemptinne (1876-1958), noted in 1950 that "the Protestants are gnawing at the principle of authority everywhere that they can undermine the authority of Belgians in the Congo. The big companies understand that Catholicism presents a stabilizing factor and for that reason, they have entrusted us the responsibility to educate." ${ }^{45}$ René Butaye (1858-1929), one of the earliest Jesuits to arrive in the Congo, put it this way: "The Jesuits had to act fast, to not allow the heresy to take root. They had to occupy the land [...] Fr. Allard was able to find a convenient spot in Kimbau [...] less than three miles away from Mwanza, the fortress of Protestantism." 46

As was briefly mentioned above, it would be wrong to assume that the relationships between the two confessions-Catholic and Protestant-were always tense, even though this was often the case. The Jesuits not only received some linguistic help from Protestant missionaries (for example, using a Kikongo dictionary written by Protestants who had been working in the region for more than fifteen years before the Jesuits arrived) but also benefited from medical services at the hand of Rev. Dr. Aaron Sims (d.1922), a Scottish missionary who was attached to the Livingstone Inland Mission (LIM) and one of the earliest Protestant missionaries to arrive in the Congo. Sims established the first church in Kinshasa for the American Baptist Missionary Union that later became the American Baptist Foreign Mission (ABFM). American pastor Thomas Moody paid an amicable visit to the Jesuit apostolic vicar of Kwango, Mgr. Stanislas De Vos (1859-1932), not only bringing some very kind words but also eggs, bananas, and some canned beans. De Vos wondered: "What do you think about these relationships between the Rev. Thomas Mondy [Moody] and the Apostolic Prefect of Kwango?"47 Another story related to the revolt

\footnotetext{
44 Boyle, "School Wars," 459.

45 Markowitz, quoted in Smith, "Here we are in full battle," 118.

46 Ibid.

47 Léon De Saint Moulin in Actes du colloque de Kimwenza, décembre 1993 (Kinshasa: Province d'Afrique Centrale, 1994), 18.
} 
of the Bapende from May to September 1931 shows there was some degree of mutual trust and cooperation between Catholics and Protestants. ${ }^{48}$ An article published in L'avenir colonial blamed the Bapende's revolt on the Protestant missionaries for having encouraged it. The Jesuit bishop, Sylvain van Hee (1875-1960), who was then apostolic vicar of Kwango, replied by defending the Protestants. He said he was not aware of any problem between the Catholics and the Protestant missionary Charles Smith, whom "I have the honor of knowing personally and whose perfect correction I highly appreciate in every aspect." 49

\section{The "Mission" Complex: Some Theological Considerations}

It is impossible to include everything that took place between the Jesuits and Protestants in the Congo in a summary account of several decades of early interactions. Further research could pay greater attention to conflict within the Jesuit mission itself, for instance, which was epitomized by the rocky relationship between van Hecxthoven and Liagre on the issue of the proliferation of farm-chapels at the expense of catechetical depth. Indeed, the concern with the numbers of converts is reminiscent of Saint Francis Xavier's (1506-52) policy in India of baptizing as many as possible and as fast as he could, leaving the work of deepening the faith for later. Likewise, churches and new posts proliferated in the Congo. Sacraments were administered in large numbers. And new recruits were added to farm-chapels. But what about the quality of the new converts' faith? These two men, van Hecxthoven and Liagre, disagreed so vehemently on the matter that they required arbitration from Brussels and Rome. Future analysis could also examine how the new Catholic social teaching informed the consciousness of the Jesuit missionaries to the Congo. This mission, in fact, opened only two years after the publication of Pope Leo XIII's encyclical Rerum novarum.

Given that Rerum novarum stressed the plight of workers in Europe against rapacious capitalist owners at a time of industrialization, what was it that

48 In La répression de la révolte des Pende du Kwango en 1931, Louis-François Vanderstraeten suggests that "Plusieurs facteurs expliquent cette révolte: l'administration particulièrement brutale du territoire de Kandale durant les dernières années; les prestations accrues exigées de la population par les compagnies H.C.B. et C.K. avec l'appui de l'Administration; les rivalités de clans dans deux chefferies voisines et l'hostilité de chefs coutumiers influents évincés par l'Administration; l'émergence d'une secte magico-religieuse qui fournit des cadres à la révolte et derrière laquelle se cachent les chefs coutumiers." Available online at http://www.i6doc.com/livre/?GCOI=28001100558340 (accessed May 23, 2017).

Smith "Here we are in full battle," 140. 
prevented the Jesuits in the Congo from implementing the spirit of human dignity and social justice in the Congo at a time when the Congolese population was being exploited by the CFS and allied companies? Was the denunciation of state brutalities simply overlooked by the Jesuits because the cause was championed by Protestants, the perceived enemies of the Catholic faith? While it is true that the Catholic Church grew in opposition to the spirit of the Enlightenment, which emphasized individual freedom and the capacity of human reason as if divorced from God and from God's law, the Jesuits harbored the suspicion that Protestantism was intimately related to the Enlightenment, given its insistence on the freedom of religion against the grasp of the Roman Catholic ecclesiastical empire. Unless the Jesuit attitude was dictated by nationalist sentiments that paralyzed commitment to social justice, one can conclude that the "erroneous" conception of civilization had colonized the intellectual structures put in place by these Jesuits to the point that they overlooked the moral abuses by the state that supported them. While Protestants and lay writers were quick to denounce colonial state abuses, some of the questions raised above regarding the Jesuit position remain largely unanswered and clearly call for further research.

\section{Bibliography}

Actes du colloque de Kimwenza, décembre 1993. Kinshasa: Province d'Afrique Centrale, 1994.

Boyle, Patrick M. "School Wars: Church, State, and the Death of the Congo." Journal of Modern African Studies 33, no. 3 (1995): 451-68.

Chômé, Jules. Indépendance congolaise: Pacifique conquête. Brussels: Editions de Remarques Congolaises, 1960.

Cline, Catherine Ann. "The Church and the Movement for Congo Reform." Church History: Studies in Christianity and Culture 32, no. 1 (1963): 46-56.

Conrad, Joseph. Heart of Darkness \& Selections from the Congo Diary. New York: Modern Library, 1999.

Dunn, Kevin C. Imagining the Congo: The International Relations of Identity. New York: Palgrave Macmillan, 2003.

Hochschild, Adam. King Leopold's Ghost: A Story of Greed, Terror, and Heroism in Colonial Africa. New York: First Mariner Book, 1999.

Krumenacker, Yves. "Le XviIIe siècle: Éveil protestant et déclin catholique ?" Cahiers d'études du religieux: Recherches interdisciplinaires 1 (2008). http://cerri.revues .org/242 (accessed May 22, 2017).

Markowitz, Marvin D. "The Missions and Political Development in the Congo." Africa: Journal of the International African Institute 40, no. 3 (1970): 234-47. 
Mayer, Ruth. Artificial Africas: Colonial Images in Times of Globalization. Hanover and London: University Press of New England, 2002.

Moreau, Edouard de. Les missions belges de 1804-1930. Brussels: Editions Jos. Vermant, 1933.

Mudimbe, V.Y. [Victor Yves]. The Idea of Africa. Bloomington: Indiana University Press, 1994.

Mudimbe, V.Y. The Invention of Africa: Gnosis, Philosophy, and the Order of Knowledge. Indianapolis: Indiana University Press, 1988.

Ng'Ekieb, Fernand Mukoso. Les origines et les débuts de la mission du Kwango (18791914). Kinshasa: Facultés Catholiques de Kinshasa, 1993.

Reardon, Ruth Slade. "Catholics and Protestants in the Congo." In Christianity in Tropical Africa, edited by C.G. [Christian Goncalves] Baëta, 83-100. Oxford: International African Institute and Oxford University Press, 1968.

Reybrouck, David Van. Congo: The Epic History of a People. New York: HarperCollins, 2014.

Smith, Robert E. "Here we are in full battle': Jesuits and Baptists in the Kwilu, Congo." American Baptist Quarterly 22, no. 2 (2003): 180-211.

Stearns, Jason K. Dancing in the Glory of Monsters: The Collapse of the Congo and the Great War of Africa. New York: PublicAffairs, 2011.

Stenström, Gösta. The Brussels Archives, 1922-1968. Uppsala: Swedish Institute of Mission Research, 2009 . 